\title{
Laboratory evaluation of Rediset modified bitumen based on rheology and adhesion properties
}

\author{
Jizhe Zhang \\ Research Associate \\ School of Civil Engineering, Shandong University \\ Jingshi Road 73\#, 250061, Jinan, Shandong Province, China \\ Tel: 86-13964032980; Email: zhangjizhe2001@163.com
}

Gordon D. Airey

Professor

Nottingham Transportation Engineering Centre, Department of Civil Engineering

University of Nottingham, University Park, Nottingham NG7 2RD, United Kingdom

\author{
James Grenfell \\ Senior Engineer \\ Australian Road Research Board, Melbourne \\ 500 Burwood Hwy, Vermont South, VIC 3133, Australia \\ Zhanyong Yao \\ Professor \\ School of Civil Engineering, Shandong University \\ Jingshi Road 73\#, Jinan, Shandong Province, China
}

\begin{abstract}
Warm mix asphalt (WMA) could significantly reduce the production temperature of asphalt mixtures. Lower production temperature meaning reduced fossil fuel consumption and greenhouse gas emission which in turn avoid environmental pollution in the road construction process. This study aims to characterise the properties of bitumen with the addition of a type of WMA additive - Rediset. The influence of Rediset on bitumen surface energy was evaluated by using the Dynamic Contact Angle (DCA) test. Complex modulus
\end{abstract}


and phase angle of bitumen were evaluated through frequency sweep test using Dynamic Shear Rheometer (DSR). The high-temperature viscosity of bitumen was measured using a corn and plate system which installed in the DSR equipment. Finally, the Pneumatic Adhesion Tensile Testing Instrument (PATTI) test was performed to measure the tensile strength and moisture susceptibility of aggregate-bitumen combinations. The results show that the Rediset reduces the surface energy of bitumen. Moreover, as seen in the DSR test, the complex modulus increased while the phase angle decreased at the low frequency range due to the addition of Rediset. The decreased bitumen viscosity because of the addition of Rediset demonstrating reduced mixing and compaction temperature of asphalt mixture. In addition, the addition of Rediset could improve the bonding strength of aggregate-bitumen combinations at medium and high service temperatures but has no influence at low temperature. Furthermore, the Rediset is able to increase the retained tensile strength which in turn reduces the moisture susceptibility of asphalt mixture.

Keywords: WMA; Rediset; Rheological property; High-temperature viscosity; PATTI; Moisture damage

\section{Introduction}

Asphalt mixture, as a widely used material, consists of aggregates and bitumen heated to high temperatures and mixed together followed by compaction to form asphalt pavement $[1,2]$. Due to growing concerns over global warming and air pollution, the area of pavement engineering has been steadily evolving over the last two decades [3]. Persistent efforts have been made by asphalt pavement researchers with aims of reducing the fossil fuel consumption and promoting sustainable development $[4,5,6]$. In this context, the WMA technology was developed and successfully applied by several countries due to its reduced 
energy consumption and pollution [7,8]. In general, the WMA is able to reduce mixing and compaction temperatures by $20-40{ }^{\circ} \mathrm{C}$, but without significantly affecting the road performance $[9,10]$.

The use of a WMA technique offers many benefits to asphalt industries. Lower mixing temperature means fuel cost savings to the contractor [11]. Also, the emission of carbon dioxide $\left(\mathrm{CO}_{2}\right)$ and other greenhouse gases are reduced in comparison with hot mix asphalt (HMA) [8,12]. In addition, lower compaction temperature demonstrates increased haul distances and cold weather paving benefits [13]. Currently, WMA can be prepared by the addition of organic additives and chemical additives or through the foaming generation process with the view of improving the workability of mixtures at reduced temperature [12, 14]. The organic additives could reduce the production temperatures by decreasing the viscosity of bituminous binders, while the chemical additives decrease the frictional forces at the aggregate-bitumen interface at high temperature range so as to reduce the production temperature $[15,16,17]$. The foaming technologies are based on the principle to expand the volume of bitumen by injecting water during the mixing process to make sure the mixture can be mixed and compacted at lower temperatures [18].

The focus of this paper is on the WMA additive - Rediset. Rediset is a multifunctional WMA additive which consists of surface active agents and anti-stripping agents. The addition of Rediset can improve the wettability of bituminous binders by reducing the surface energy at temperatures below its typical mixing temperature $[19,20]$. At the same time, the anti-stripping agents can encourage the aggregate-bitumen adhesion so as to improve the bitumen resistance to displacement by water. Its melting range is between $80^{\circ} \mathrm{C}$ and $90^{\circ} \mathrm{C}$. The melting temperature is high enough to make Rediset maintains its solid mode at pavement service temperatures to produce stiffening effect. At temperatures above its melting 
point, Rediset decreases the surface tension of bitumen, reduces the interfacial friction between bitumen and aggregate and improve the wettability of aggregate by bitumen [21].

In this study, a type of solid Rediset pellet was blended with base bitumen with the view to understand the contribution of Rediset to related bitumen properties. As the Rediset containing surface active agent, the influence of Rediset on bitumen surface energy was obtained by using the DCA test. The visco-elasitc behaviour of bitumen (including complex modulus and phase angle) from low to high service temperatures was evaluated through frequency sweep test using DSR. In addition, the high-temperature viscosities of bitumen were measured using a developed corn and plate system which installed in the DSR equipment. Furthermore, the PATTI test was used to measure the strength of aggregate-bitumen bond at different temperatures. Finally, the moisture resistance of different aggregate-bitumen bonds were evaluated through the PATTI test. The retained tensile strength, which is the ratio of wet bonding strength to the dry bonding strength, were used to assess the moisture susceptibility.

\section{Materials}

\subsection{Bitumen}

The bitumen used in this research was a 40/60 penetration grade base bitumen with the detailed parameters showing in Table 1.

Table 1 . Empirically properties of $40 / 60$ pen bitumen

\begin{tabular}{|l|c|}
\hline \multicolumn{1}{|c|}{ Property } & Values \\
\hline Penetration at $25^{\circ} \mathrm{C}(0.1 \mathrm{~mm})$ & 42 \\
\hline Softening point $\left({ }^{\circ} \mathrm{C}\right)$ & 51.2 \\
\hline Density at $25^{\circ} \mathrm{C}\left(\mathrm{kg} / \mathrm{m}^{3}\right)$ & 1035 \\
\hline Flash point $\left({ }^{\circ} \mathrm{C}\right)$ & 230 \\
\hline Solution in Xylene $(\%)$ & 99 \\
\hline
\end{tabular}


In this study, a type of WMA agent named Rediset was used as the WMA additive. Rediset is a composite material which contains both surface active agents and organic additives. The surface active agents could improve the wetting of aggregate by bitumen by reducing the surface energy of bituminous binders and reduce the interfacial frictions between bitumen and aggregate. The Rediset also contains anti-stripping agent which promotes the adhesion between aggregate and bitumen which in turn improves the moisture resistance of asphalt mixtures. Table 2 shows the basic properties of Rediset.

Table 2. Physical properties of Rediset

\begin{tabular}{|l|c|}
\hline \multicolumn{1}{|c|}{ Property } & Result \\
\hline Appearance at $25^{\circ} \mathrm{C}$ & Brown pastilles \\
\hline Melting range $\left({ }^{\circ} \mathrm{C}\right)$ & $80-90$ \\
\hline Bulk density $\left(\mathrm{g} / \mathrm{cm}^{3}\right)$ & 0.55 \\
\hline Flash point $\left({ }^{\circ} \mathrm{C}\right)$ & $>150$ \\
\hline
\end{tabular}

\subsection{Aggregates}

In this paper, two types of aggregates named limestone and granite were used to investigate the influence of Rediset on the moisture susceptibility of aggregate-bitumen combinations. As from different quarries, these two aggregates must have different mineral compositions and surface properties and these differences must influence the bonding strength between aggregate and bitumen. So, the mineral properties of aggregates which including mineral composition, surface texture and grain size were analysed by using a mineral liberation analyser (MLA). In this research, an FEI Quanta 600 SEM was used to evaluate the mineral properties of aggregates with the detailed testing procedures could be seen elsewhere [1].

The MLA scans with the summaries of mineral compositions, as determined by MLA, are provided in Figure 1. The results show that these two aggregates have significantly different 
mineral composition with the predominant phase of limestone is calcite ( $99.33 \%$ by weight). In terms of the granite, it is made up of several different minerals with the predominant phase being albite ( $73.17 \%$ by weight), followed by significant quantities of chlorite and anorthite with the content of $15.58 \%$ and $10.75 \%$, respectively.

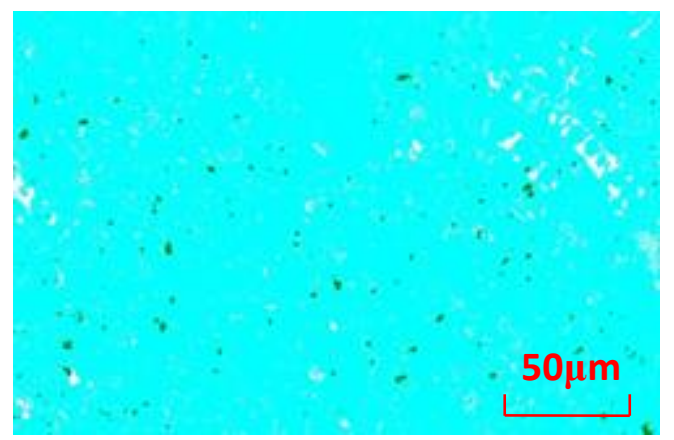

(a)
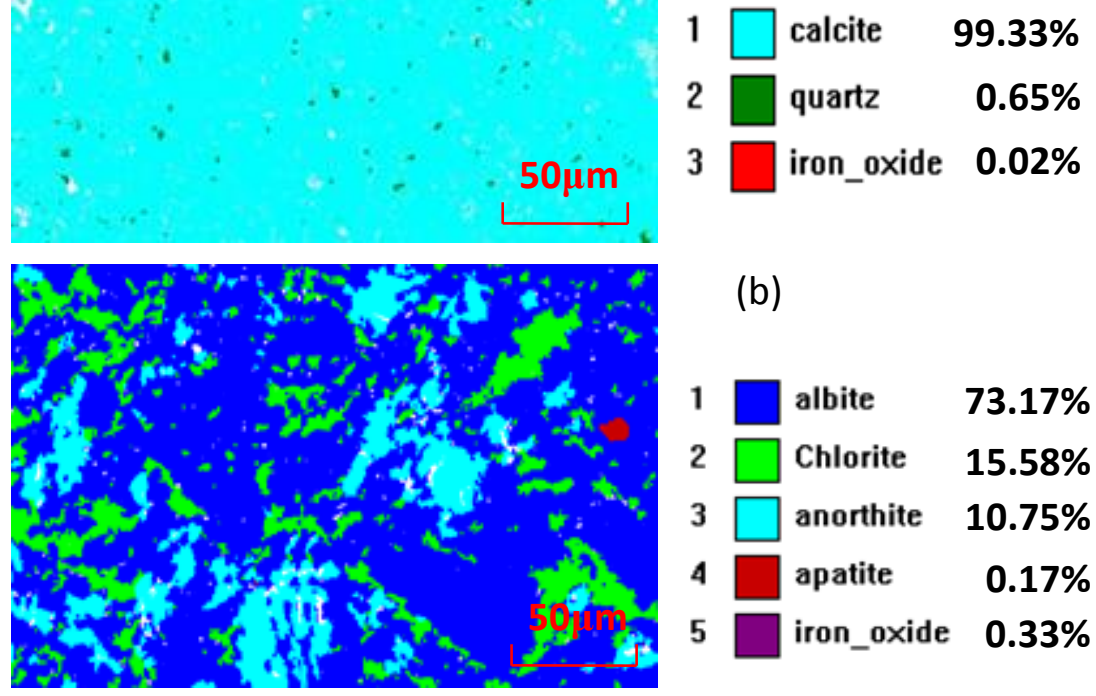

(b)

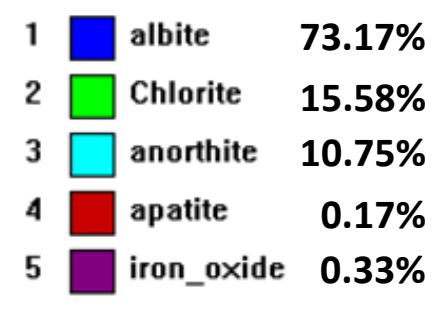

Figure 1. Mineral mosaic of (a) limestone and (b) granite [22]

\section{Experimental procedures}

\subsection{WMA binder preparation}

Before evaluating the influence of Rediset on bitumen properties, it is of importance to prepare well blended WMA binders. In this study, a high speed shear mixer was used to prepare the WMA binders, as shown in Figure 2. The detailed procedures for sample preparation are given as follows [23]:

- Heat the base bitumen to $130^{\circ} \mathrm{C}$ until it has melted;

- The WMA Rediset was added with the weight percentage of $1 \%, 2 \%$ and $3 \%$, respectively; 
- The bitumen container was placed into an oven at a temperature of $130^{\circ} \mathrm{C}$ for $10 \mathrm{~min}$;

- High speed mixer was applied at the speed of $2500 \mathrm{rpm}$ for $10 \mathrm{~min}$ to decrease the particle size of Rediset and achieve a good homogeneity.

- The well blended binders are named Rediset modified binders and stored for further tests.

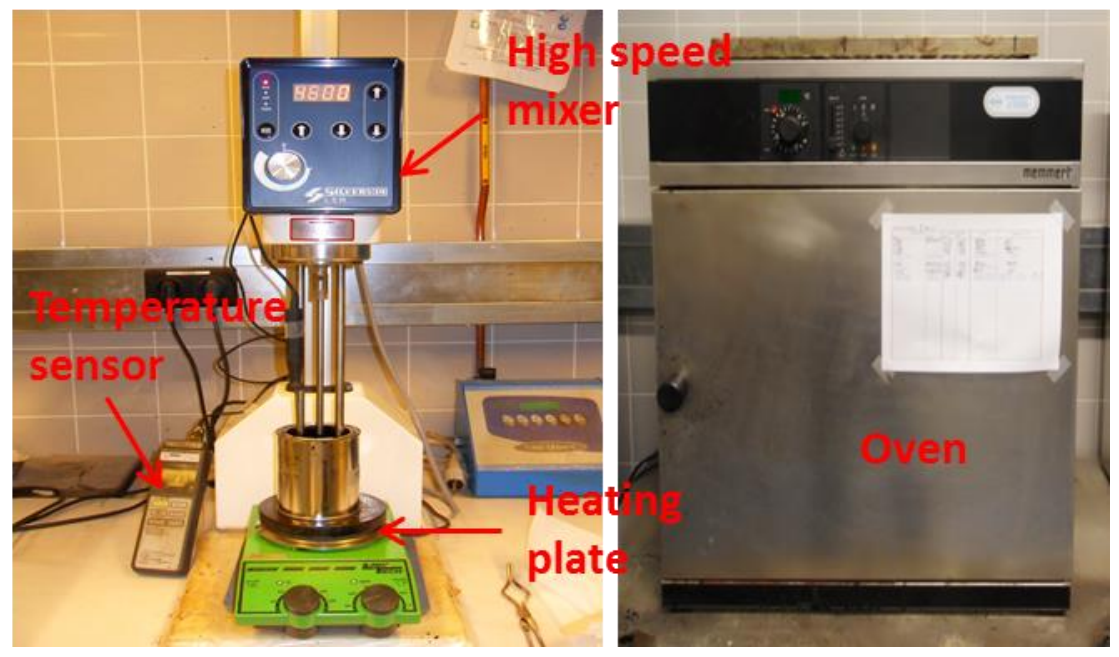

Figure 2. Equipment used to prepare warm mix bitumen

\subsection{Surface energy of bitumen}

A Cahn Model DCA analyser, as shown in Figure 3, was used to measure the contact angles of probe liquids on bitumen surface and the results were then used to calculate the surface energy of bitumen. Because there are three unknown surface energy parameters for bitumen, this study selected three probe liquids included water, glycerol and di-iodomethane with their surface energy components showing in Table 3 [22].

Table 3. Surface energy components $\left(\mathrm{mJ} / \mathrm{m}^{2}\right)$ of the probe liquids

\begin{tabular}{|c|c|c|c|c|}
\hline Probe liquid & $\gamma^{L W}$ & $\gamma^{+}$ & $\gamma^{-}$ & $\gamma^{T}$ \\
\hline Water & 21.8 & 25.5 & 25.5 & 72.8 \\
\hline Glycerol & 34.0 & 3.92 & 57.4 & 64.0 \\
\hline Diiodomethane & 50.8 & 0 & 0 & 50.8 \\
\hline
\end{tabular}


Notes: $\gamma^{L W}$, Lifshitz van der Waals component; $\gamma^{+}$, Lewis acid component; $\gamma^{-}$, Lewis base component; $\gamma^{T}$, total surface energy.
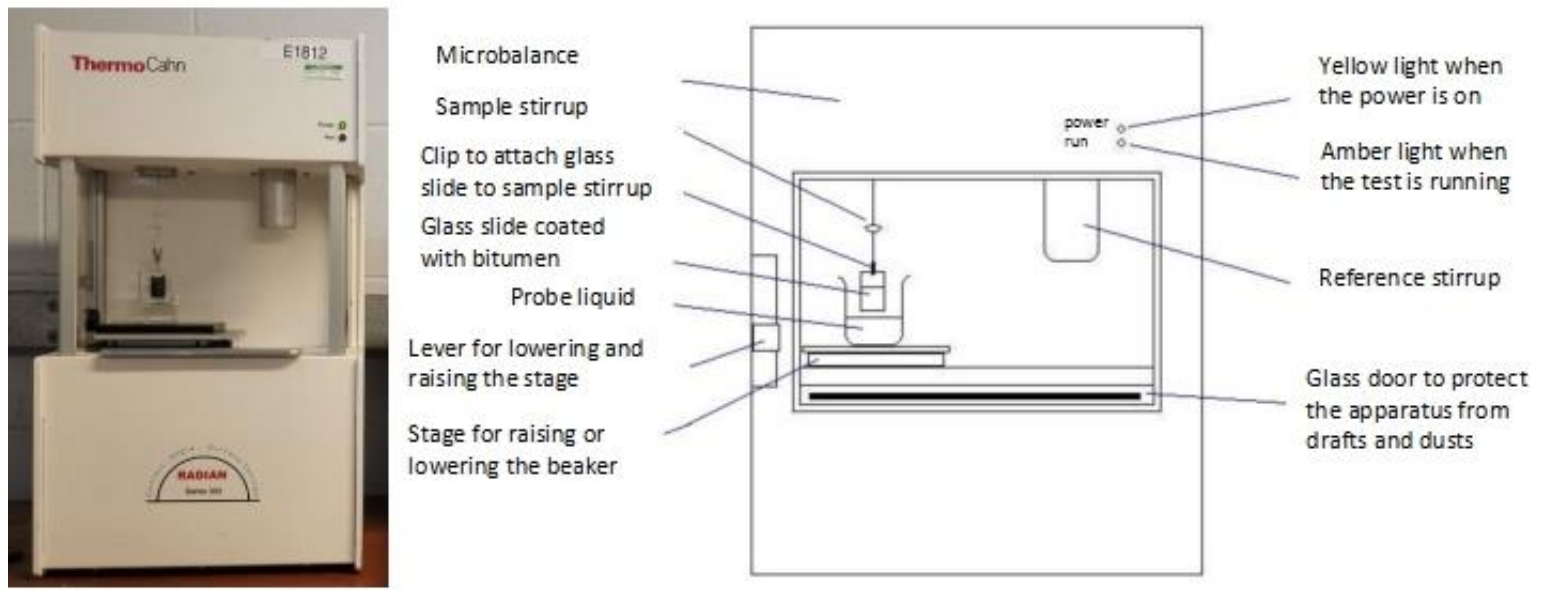

Figure 3. Schematic of dynamic contact angle analyser [24]

In this test, the microbalance measured and recorded the weight of the slide during the advancing and receding process. The recorded mass-depth relationships by the microbalance during immersing and receding of the plate were used to calculate the contact angle between probe liquid and bitumen. The contact angle between the probe liquid and surface of the bitumen-coated slide was calculated from the following equation [25]:

$\cos \theta=\frac{\Delta F+V_{i m}\left(\rho_{L}-\rho_{\text {air }} g\right)}{P_{t} \gamma_{L}}$

where $P_{t}$ is the perimeter of the glass plate with bitumen coating, $\gamma_{L}$ is the total surface energy of probe liquid, $\Delta F$ is the weight difference of plate before and after submerged in probe liquid, $V_{i m}$ is the volume of plate which immersed in the liquid, $\rho_{L}$ is the probe liquid density, $\rho_{a i}$ is the density of air, and $g$ is the gravitational force. 
With the view of calculating the surface energy components of bitumen, the contact angles between the bitumen and the three selected probe liquids were measured. The obtained contact angle values and the surface energy components of probe liquid were then applied to the Young-Dupre equation for the work of adhesion $\left(W_{S L}\right)$ between the two materials:

$W_{S L}=\gamma_{L}(1+\cos \theta)=2 \sqrt{\gamma_{S}^{L W} \gamma_{L}^{L W}}+2 \sqrt{\gamma_{S}^{-} \gamma_{L}^{+}}+2 \sqrt{\gamma_{S}^{+} \gamma_{L}^{-}}$

where $\theta$ is the contact angle between bitumen and probe liquid, $S$ represents the solid bitumen surface and $L$ represents the probe liquid.

The three surface energy components $\left(\gamma^{L W}, \gamma^{+}, \gamma^{-}\right)$of bitumen were finally determined by solving three equations with known contact angle values and surface energy components of three probe liquids.

\subsection{Rheological measurements and strain decision}

The influence of Rediset on the rheological behaviours of bitumen were evaluated using the AR2000ex DSR equipment. The frequency sweep test was performed under strain controlled loading with the sweep frequency from $0.1 \mathrm{rad} / \mathrm{s}(0.016 \mathrm{~Hz})$ to $400 \mathrm{rad} / \mathrm{s}(63.66 \mathrm{~Hz})$. All specimens were measured at eight temperatures ranging from $-10^{\circ} \mathrm{C}$ to $60^{\circ} \mathrm{C}$ and the values of complex modulus $\left(\mathrm{G}^{*}\right)$ and phase angle $(\delta)$ were recorded. It should be noticed that the frequency sweep test must performed within the linear visco-elastic range. According to the linear viscoelasticity theory, the ratio of stress to strain must be independent to the strain magnitude. For this reason, strain sweep tests were first performed at a constant sweep frequency of $10 \mathrm{rad} / \mathrm{s}$ with increased strain. The relationships between strain and modulus are shown in Figure 4. As all strains are within the linear viscoelastic region, any strain can be selected for frequency sweep test. Table 4 provides the testing conditions for DSR test. 


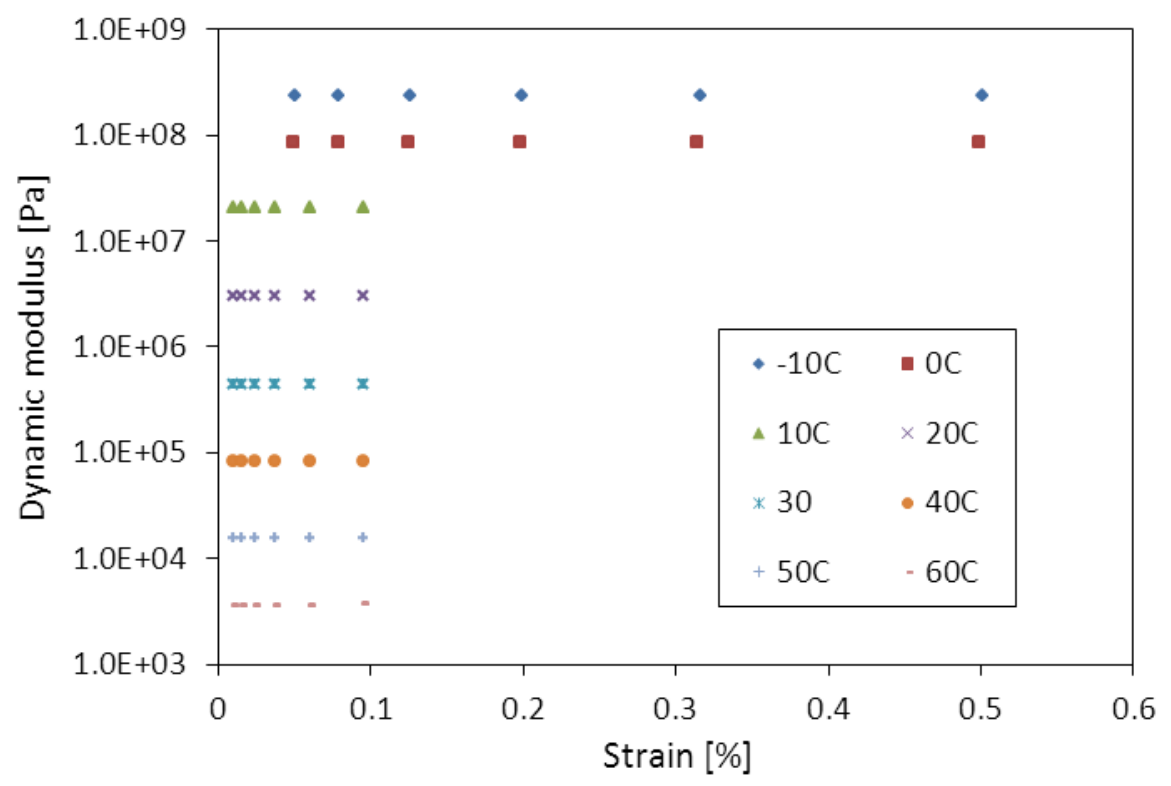

Figure 4. Strain sweep results of base bitumen at different temperatures at 10rad/s

Table 4. Conditions of DSR test

\begin{tabular}{|c|c|c|c|c|c|c|c|c|}
\hline \multirow{2}{*}{ Sample } & \multicolumn{6}{|c|}{ Base bitumen and modified bitumen applied the } \\
& \multicolumn{7}{|c|}{ same strain } \\
\hline Temperature $\left({ }^{\circ} \mathrm{C}\right)$ & -10 & 0 & 10 & 20 & 30 & 40 & 50 & 60 \\
\hline Strain Control $(\%)$ & 0.03 & 0.04 & 0.05 & 0.05 & 0.05 & 0.05 & 0.1 & 0.1 \\
\hline Parallel Plate Diameter & \multicolumn{3}{|c|}{$8 \mathrm{~mm}$} & \multicolumn{5}{c|}{$25 \mathrm{~mm}$} \\
\hline Sample Thickness & \multicolumn{6}{|c|}{$2 \mathrm{~mm}$} \\
\hline Frequency & \multicolumn{6}{|c|}{$0.1-400 \mathrm{rad} / \mathrm{s}(0.016-63.66 \mathrm{~Hz})$} \\
\hline
\end{tabular}

\subsection{High-temperature viscosity evaluation}

Because Rediset is a type of WMA additive, its addition must influence the fluidity of bitumen at high temperatures so as to reduce the production and compaction temperatures of asphalt mixtures. Therefore, it is of importance to understand the viscosity change after the addition of Rediset. The influence of Rediset on the viscosity of bitumen was evaluated by using the cone and plate method at temperatures from $100^{\circ} \mathrm{C}$ to $150^{\circ} \mathrm{C}$. This method has been successfully used by previous researchers [26]. The shear rate dependence of the torque was 
measured by using a cone and plate device which was installed on the AR2000ex DSR, as shown in Figure 5. After testing, the dynamic viscosity of bitumen was then calculated based on the European standard (pr EN 13702-1), as shown in Equation 3 and 4.

The shear stress was obtained from:

$$
\tau=\frac{3 T}{2 \pi R^{3}}
$$

where, $T$ is the torque, $R$ is the radius of the cone.

Then, the viscosity was deduced by:

$$
\eta=\frac{\tau}{\gamma}=\frac{3 T}{2 \pi R^{3} \gamma}
$$

where, $\gamma$ is the shear rate $(\mathrm{rad} / \mathrm{s})$.
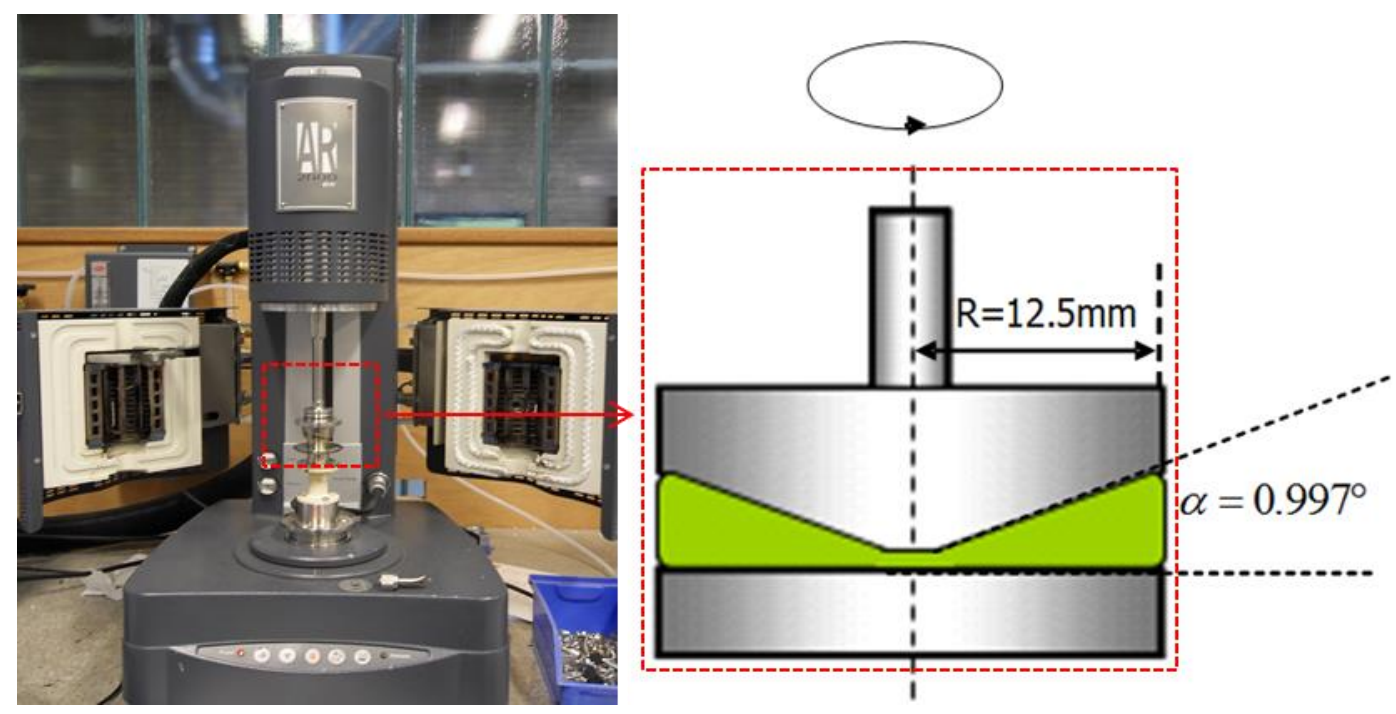

Figure 5. DSR equipment and the schematic image of a corn and plate device

\subsection{Aggregate-bitumen bonding evaluation}

Because the Rediset is a multifunctional WMA additive, the addition of Rediset may influence the bonding strength between aggregate and bitumen from low to high service temperatures. With the view of evaluating the tensile strength of aggregate-bitumen 
combinations, the PATTI test was conducted to measure the cohesive or adhesive bonding strength of aggregate-bitumen-pull stub sandwiched samples. The PATTI was developed by the National Institute of Standards and Technology (NIST) with the components shown in Figure $6 \mathrm{a}$. In Figure 6b, the cross-sectional schematic shows that the piston attached to the reaction plate and these two parts were then screwed on the pull stub to form a fixed system. The detailed introduction of sample preparation and testing procedures could be seen elsewhere [1].
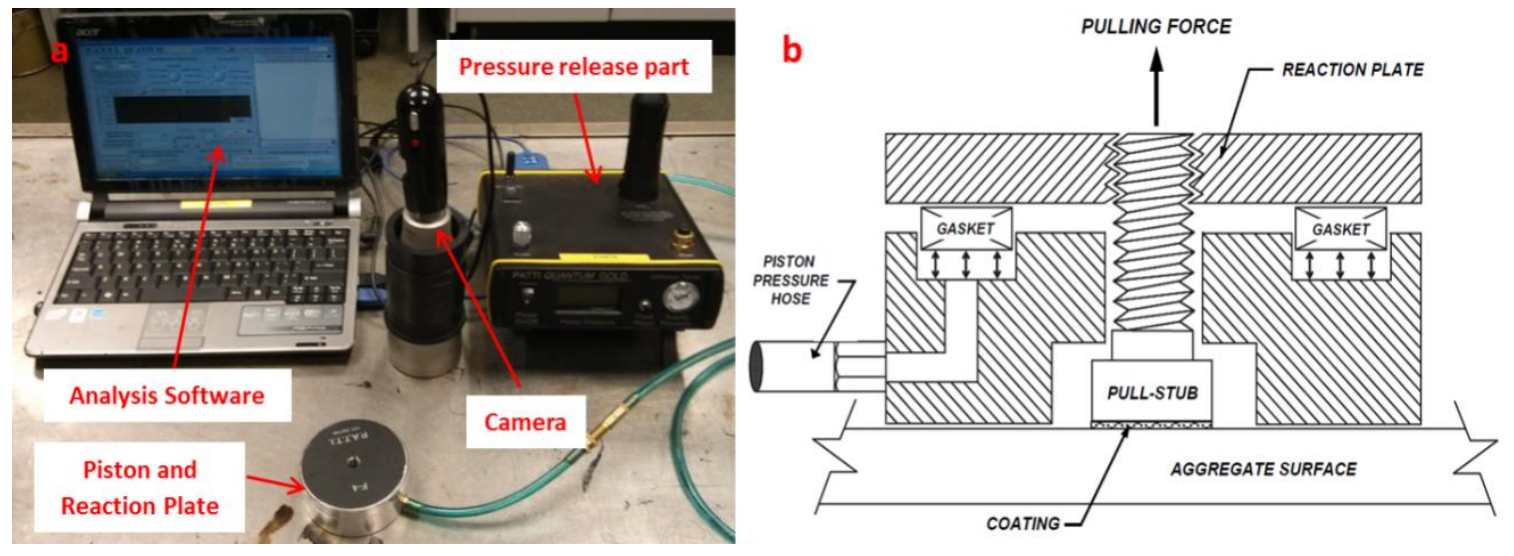

Figure 6. PATTI Test: (a) set-up (b) Cross-section view of piston attached to pull-stub [27]

As a portable adhesion tester, the PATTI equipment has no temperature control system to maintain the specimen temperature during testing. Because bitumen is a visco-elastic material, its property is very sensitive to the temperature change. If performing the PATTI test without strict temperature control, the variation of temperature may influence the tensile strength values and misleading the final conclusion.

In this research, the PATTI equipment and the environmental chamber were assembled together to evaluate the tensile strength under well controlled temperature, as shown in Figure 7. The reaction plate was placed inside the environmental chamber connected with the pressure release part by using the pressure air pipe through a round hole with the diameter of $50 \mathrm{~mm}$ placed on the broadside of the environmental chamber. A rubber plug with the same dimensions as the round hole was used to block the hole to maintain the inside temperature. 
The environmental chamber could accurately control the temperature from $-10^{\circ} \mathrm{C}$ to $40^{\circ} \mathrm{C}$ with the precision of $\pm 0.1{ }^{\circ} \mathrm{C}$. With the view of getting a homogeneous temperature distribution, specimens were first placed in the environmental chamber at the selected temperature for 3 hours. Before testing, one conditioned specimen was installed on the piston and reaction plate followed by 1 hour conditioning. During testing, the PATTI equipment was controlled outside the chamber to release constant rate of pulling pressure to detach the specimen and record the maximum tensile pressure.

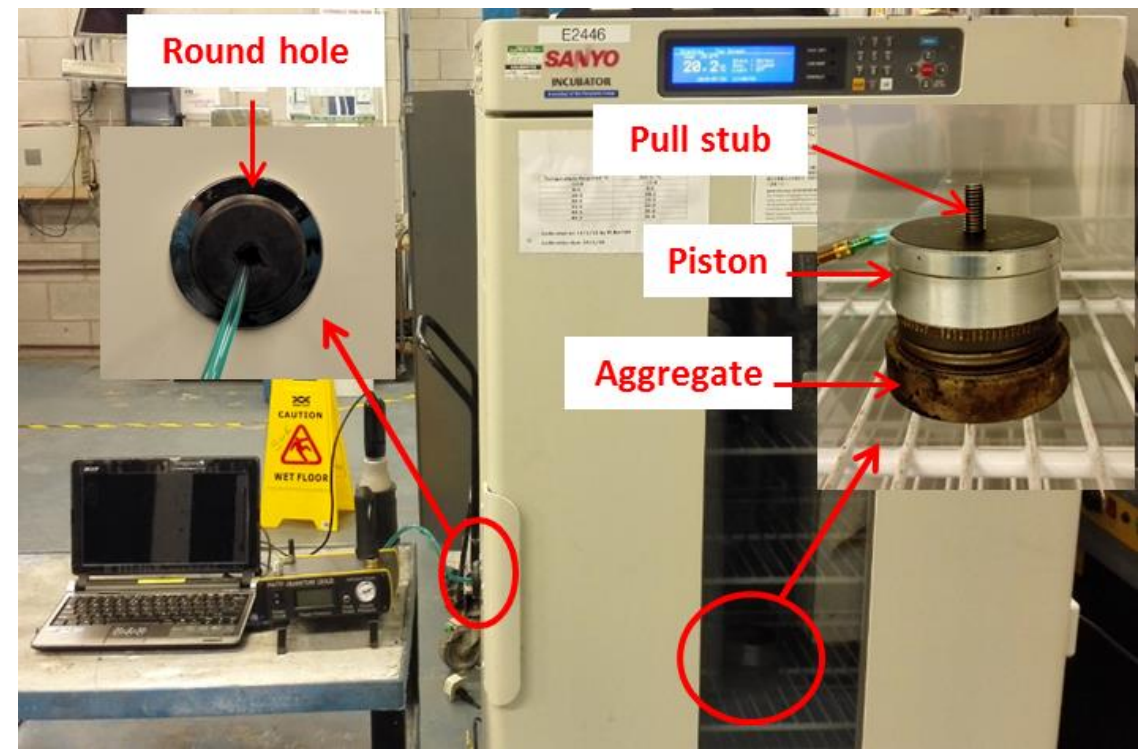

Figure 7. The PATTI equipment connected with environmental chamber to control temperature

\subsection{Moisture damage evaluation}

The Rediset contains anti-stripping agents which may improve the moisture susceptibility of asphalt mixtures theoretically. By evaluating the contribution of Rediset to moisture resistance, specimens for PATTI test were first conditioned in water to simulate the moisture attack. In this section, the whole specimens were immersed in water with the duration of 7 days and 14 days at controlled temperature of $20^{\circ} \mathrm{C}$. During the conditioning period, water molecules penetrated into the aggregate and finally reached to the aggregate-bitumen 
interface. After conditioning, the retained bonding strength need to be measured immediately using the PATTI test.

\section{Results and discussion}

\subsection{Surface energy of bitumen}

The contact angles between bitumen and probe liquids were measured by using the DCA test. These contact angle values and the surface components of the probe liquid, as shown in Table 3, were applied to Equation 2 to calculate the bitumen surface energy. The obtained surface energy components of different bitumens were presented in Table 5.

Table 5. Surface energy components $\left(\mathrm{mJ} / \mathrm{m}^{2}\right)$ of bitumen

\begin{tabular}{|c|c|c|c|c|}
\hline Sample type & $\gamma^{L W}$ & $\gamma^{+}$ & $\gamma^{-}$ & $\gamma^{T}$ \\
\hline Bitumen & 37.47 & 0.01 & 1.94 & 37.80 \\
\hline $\mathrm{B}+1 \% \mathrm{R}$ & 37.25 & 0.02 & 1.95 & 37.62 \\
\hline $\mathrm{B}+2 \% \mathrm{R}$ & 37.04 & 0.01 & 2.01 & 37.31 \\
\hline $\mathrm{B}+3 \% \mathrm{R}$ & 36.82 & 0.02 & 2.22 & 37.02 \\
\hline
\end{tabular}

From this table it can be seen that the Lifshitz van der Waals components $\left(\gamma^{L W}\right)$ are obviously higher than the acid $\left(\gamma^{+}\right)$and base $\left(\gamma^{-}\right)$components. In terms of the same bitumen, the base component $\left(\gamma^{-}\right)$value is higher than the acid $\left(\gamma^{+}\right)$component value. The changes in surface energy components due to the addition of Rediset could also be observed. It can be seen that the base bitumen shows the highest total surface energy value and Lifshitz van der Waals component value. With the addition of Rediset, the Lifshitz van der Waals component experienced a slightly decrease with the result dropping to the lowest value when the Rediset dosage reaches $3 \%$. In contrast, the base component shows an increasing trend with the addition of Rediset. However, in terms of the acid component, the Rediset seems have no influence on its value. Furthermore, the results for the Rediset modified binders exhibited a 
slightly lower total surface energy compared to the result for base bitumen demonstrating that the Rediset decreases the surface energy of bitumen. Theoretically, the Rediset improves the wettability of bitumen to aggregate surface and reduces the interfacial frictions between bitumen and aggregate which in turn could reduce the production as well as the compaction temperatures of asphalt mixtures. This phenomenon has been proved by previous researchers $[28,29]$.

\subsection{Rheological properties}

After frequency sweep test, the master curves of complex modulus were produced according to the time-temperature correspondence principle with a reference temperature of $20^{\circ} \mathrm{C}$, as shown in Figure 8. In the high frequency region which corresponding to low temperature, all samples begin to approach an asymptotic behaviour corresponding to the glassy limit of the bitumen stiffness modulus. The master curves of all samples overlapped in this region meaning the addition of Rediset did not affect the binder stiffness. As frequency decreases corresponding to increase temperature, the binder stiffness reduced for all samples. In this region, the complex modulus of base bitumen and Rediset modified binders only show tiny difference, but the influence is not regular. As the frequency decreases further, the complex modulus values decrease continuously. Specimens containing Rediset show higher complex modulus in comparison with the base bitumen, higher Rediset dosage results in higher complex modulus values. 


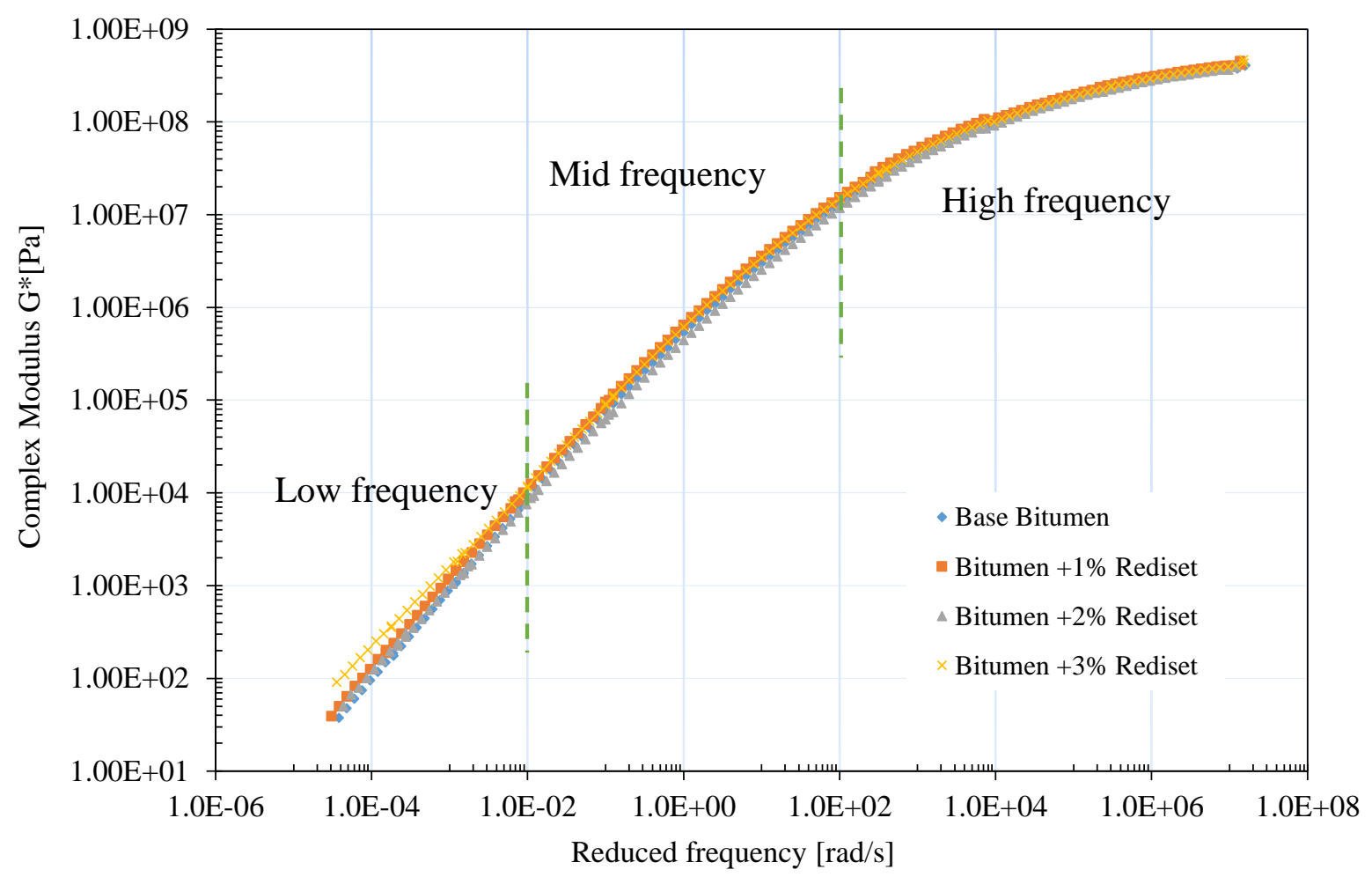

Figure 8. Complex modulus master curves of all samples at a reference temperature of $20^{\circ} \mathrm{C}$

Figure 9 shows the phase angle master curves achieved according to the time-temperature correspondence principle as mentioned above. It is generally considered that the phase angle $(\delta)$ is more sensitive to the chemical structure variation in comparison with the complex modulus. This indicates the visco-elastic behaviour of tested binders. The phase angle responses of the specimens with Rediset are different from the base bitumen in the low frequency region. In this region, the specimen which contains the highest dosage of Rediset has the lowest phase angle. In the mid frequency region, the phase angles of all specimens decreased continually. The contribution of Rediset to phase angle becomes less obvious. At high frequencies all specimens have the lowest phase angle meaning the largest elastic components. The Rediset cannot influence the phase angle any more in this region. So, the Rediset only improve the elastic properties of bitumen at high service temperatures. 
Figure 9. Phase angle master curves of all samples at a reference temperature of $20^{\circ} \mathrm{C}$

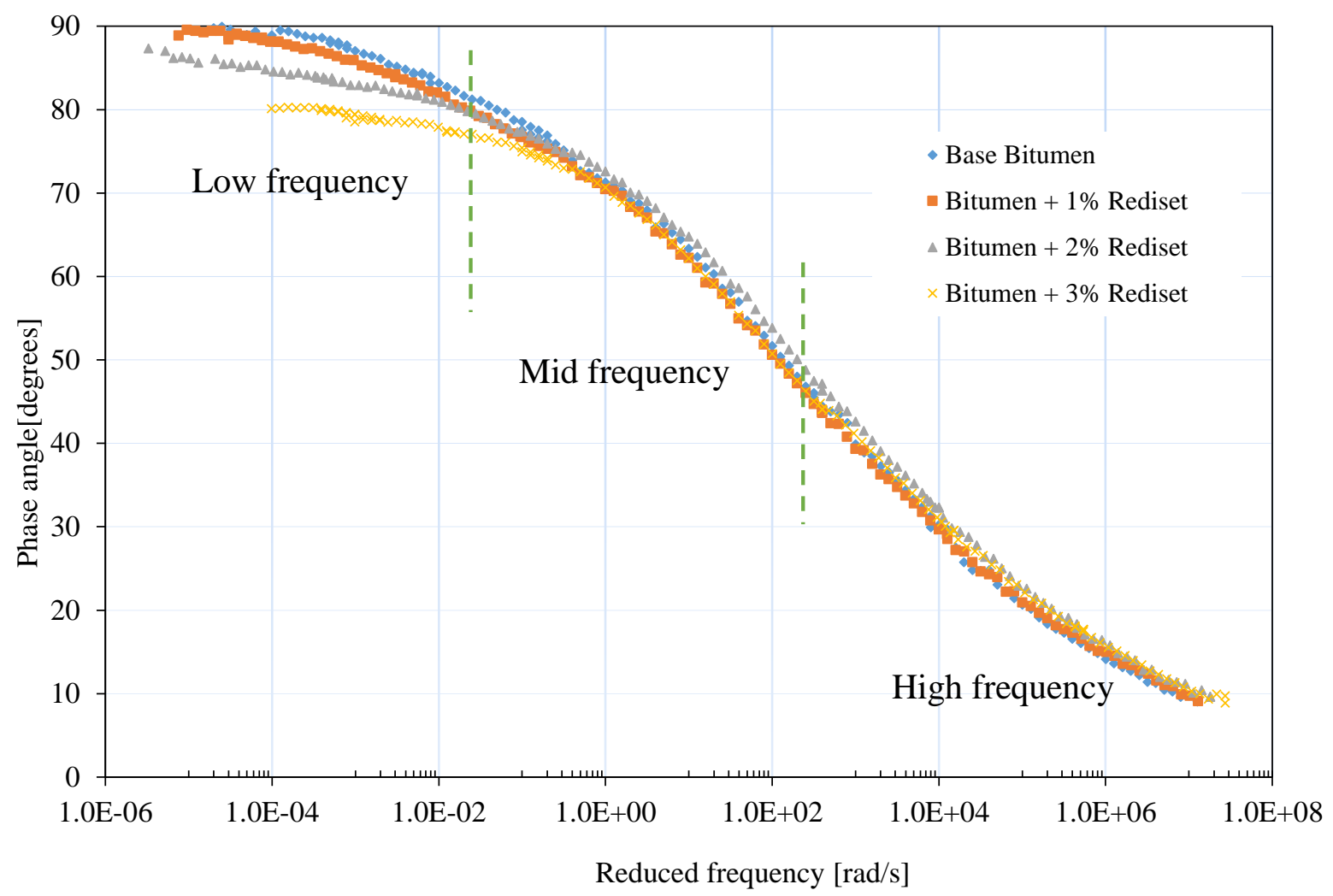

The relationship between complex modulus and phase angle was also used to evaluate the rheological properties of bitumen. It is recognised that the rutting parameter, $G^{*} / \sin \delta$ at 10 $\mathrm{rad} / \mathrm{s}$ angular frequency, developed by the Strategic Highway Research Program (SHRP) is generally correlated with rutting properties of the mixtures [30]. The bitumen is considered to be rutting resistant if the rutting parameter value is above $1 \mathrm{kPa}$ at a frequency of $10 \mathrm{rad} / \mathrm{s}$ [31]. Figure 10 shows the $\mathrm{G}^{*} / \sin \delta$ versus temperatures for base bitumen and bitumen $+3 \%$ Rediset. It is clear that the pavements are more susceptible to rutting at high service temperature when the bitumen has lower rutting parameter value. Furthermore, the Rediset modified bitumen having slightly higher $\mathrm{G}^{*} / \sin \delta$ value than the base bitumen indicating limited positive effect of Rediset on rutting resistant of asphalt mixture. The limiting high temperatures which corresponding to $\mathrm{G} * / \sin \delta=1 \mathrm{kPa}$ were calculated according to the regression equations as shown in Figure 10, with values of $62.8^{\circ} \mathrm{C}$ and $65.2^{\circ} \mathrm{C}$ for base 
bitumen and bitumen $+3 \%$ Rediset, respectively. So, the addition of Rediset results in rutting resistance improvement.

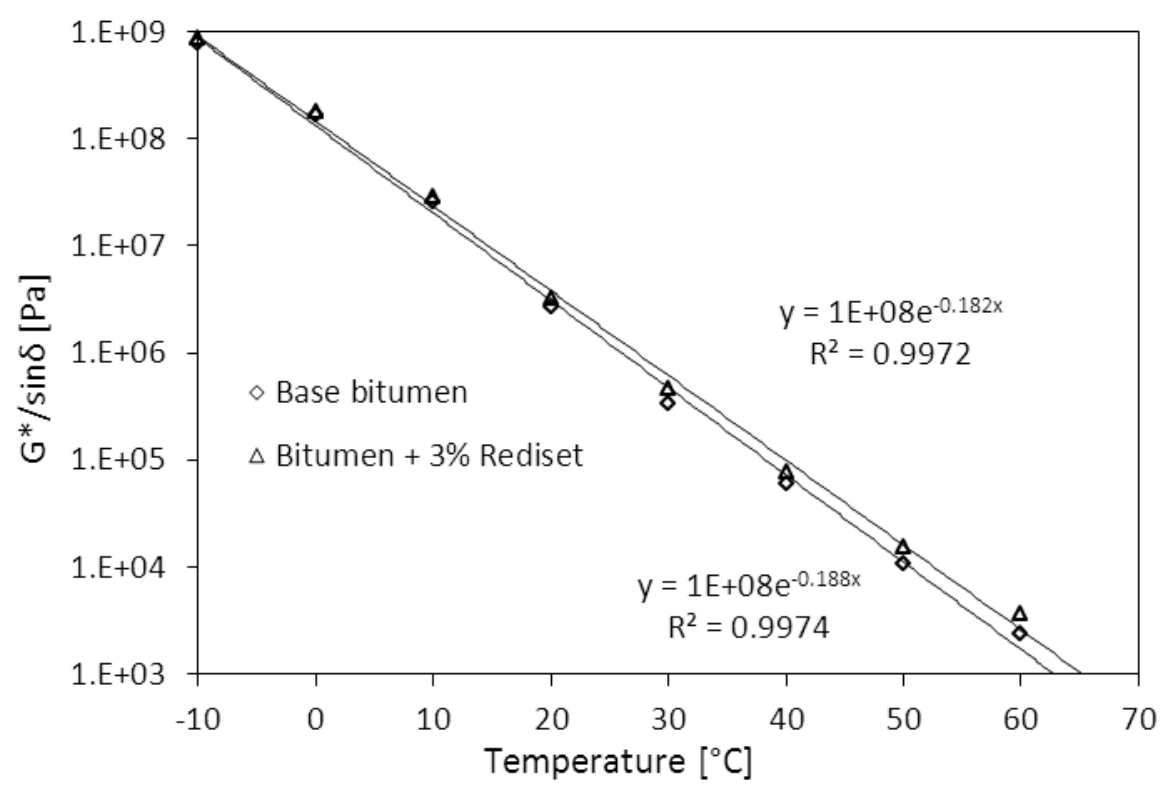

Figure 10. Effect of temperature on rutting parameter for base bitumen and Rediset modified bitumen at a frequency of $10 \mathrm{rad} / \mathrm{s}$.

\subsection{High-temperature viscosity}

Figure 11 plotted the changes of shear stress with the increase of shear rate at $130^{\circ} \mathrm{C}$. Some irregular data could be observed at the shear rate lower than $1 \mathrm{rad} / \mathrm{s}$. In contrast, when the shear rate goes above $1 \mathrm{rad} / \mathrm{s}$, the shear stress and shear rate showed linear relationships. This demonstrated that all samples behaved more like a Newtonian fluid with the shear stress almost proportional to the shear rates. Similar trends were observed for the shear stress-rate relations at other temperatures. Because all specimens shown Newtonian behaviour in the temperature region of $100^{\circ} \mathrm{C}-150^{\circ} \mathrm{C}$, it is reasonable to select any shear stress values higher than $1 \mathrm{rad} / \mathrm{s}$ to calculate the dynamic viscosity. In this research, shear rate with $500 \mathrm{rad} / \mathrm{s}$ was chosen to evaluate the dynamic viscosity. 


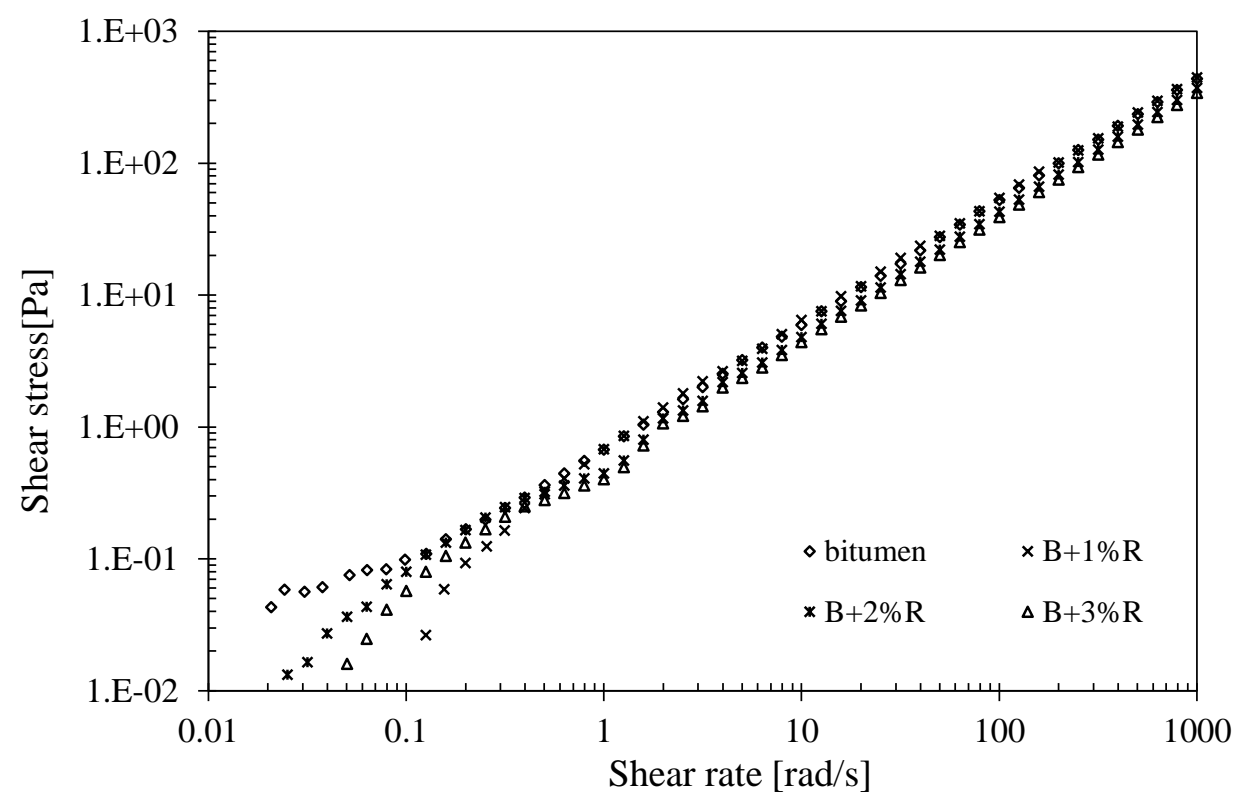

Figure 11. Shear stress versus shear rate at $130^{\circ} \mathrm{C}[23]$

The average viscosity of all bitumen at each temperature were calculated and shown in Figure 12. It can be seen that the viscosity of all specimens show index relationship with the temperature increasing. After adding Rediset, the viscosity values experienced a gradual decrement trend with the specimen contains 3\% Rediset results in the lowest value. This could be attributed to the physical properties of Rediset. As the melting temperature of Rediset is almost $90^{\circ} \mathrm{C}$, the Rediset liquefied when the temperature beyond its melting point. So, in the temperature region of $100^{\circ} \mathrm{C}-150^{\circ} \mathrm{C}$, the Rediset is fully miscible in the bitumen and reduces the bitumen viscosity. It is demonstrated that the Rediset plays as a flow improver to reduce the viscosity of bitumen at high temperature which in turn decrease the mixing and compacting temperatures. 


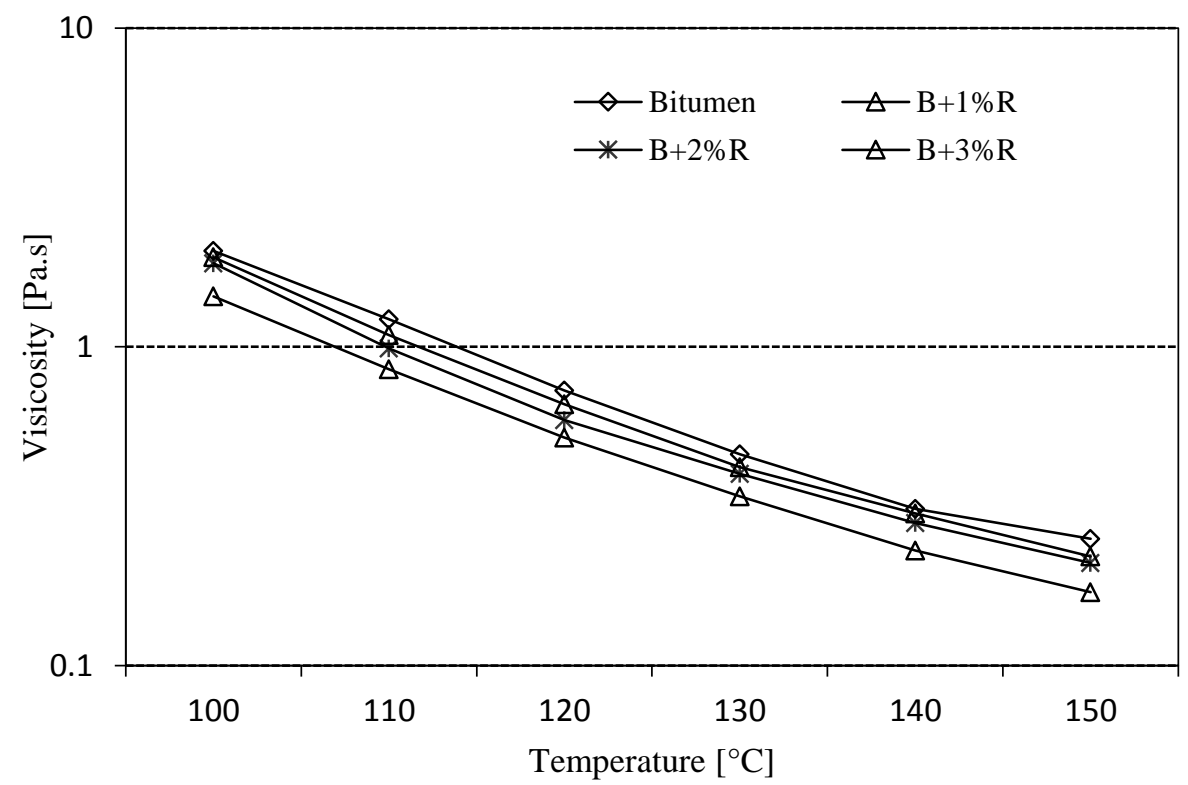

Figure 12 . Viscosity curve of all samples over the temperature range of $100^{\circ} \mathrm{C}-150^{\circ} \mathrm{C}$

\subsection{Influence of Rediset on bonding strength}

The bonding strength of of aggregate-bitumen combinations were evaluated by using the PATTI test in this section. The detailed procedures for PATTI specimen preparation could be seen in [22].

With the view of evaluating the influence of Rediset on the bonding strength of aggregate-bitumen combination at different service temperatures, the PATTI test was conducted at $-10^{\circ} \mathrm{C}, 10^{\circ} \mathrm{C}$ and $40^{\circ} \mathrm{C}$, respectively. Because the aggregate-bitumen interfaces normally break at the bitumen film and result in cohesive failure in dry condition, the aggregate type has no influence on the bonding strength. So, in this section, only one aggregate (Granite) was selected for analysis.

Four test were performed for specimens at each temperature and the average tensile strength as well as the standard deviation are shown in Figure 13. The higher tensile strength values typically indicate better performance of asphalt mixtures to resist thermal cracking and permanent deformation. It is clear that the tensile strength values experienced a decline with 
the temperature increases from $-10^{\circ} \mathrm{C}$ to $40^{\circ} \mathrm{C}$. In terms of the same temperature, the addition of Rediset influences the tensile strength values with different extents. It can be seen that the tensile strength value at $20^{\circ} \mathrm{C}$ shows an increasing trend from $1855 \mathrm{kPa}$ to $1918 \mathrm{kPa}$ with the addition of Rediset. The same trend also observed at $40^{\circ} \mathrm{C}$ with the tensile strength value increased from $527 \mathrm{kPa}$ to $582 \mathrm{kPa}$. The improved tensile strength at high temperatures correlated well with the results in section 4.2 with the Rediset increased the complex modulus of bitumen at high in-service temperatures. This result indicates that the addition of Rediset may improve the cracking and deformation resistance of asphalt mixture at medium and high service temperature due to the enhance of tensile strength. However, the tensile strength value of all specimen are nearly the same at $-10^{\circ} \mathrm{C}$ regardless of the Rediset additive. This demonstrated that the addition of Rediset may have no contribution to the thermal cracking resistance of asphalt mixture at low service temperature.

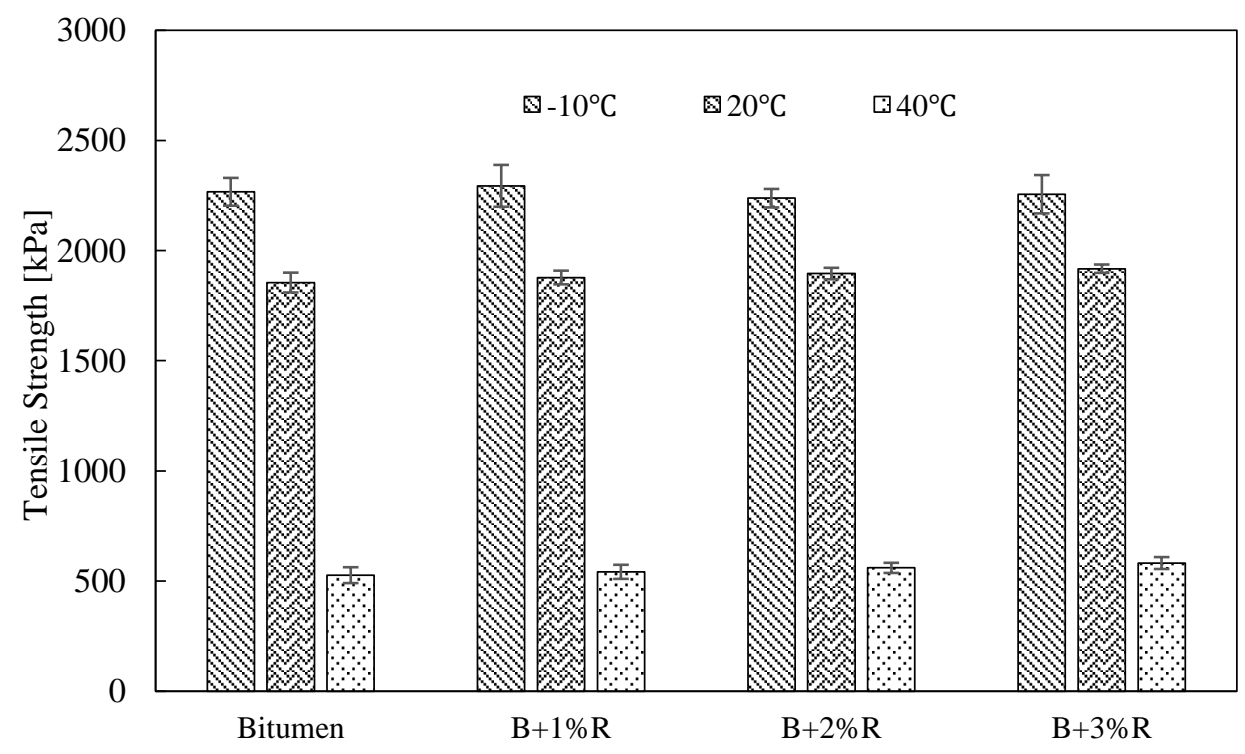

Figure 13. Tensile strength $(\mathrm{kPa})$ of aggregate-bitumen combinations at different temperatures

4.5 Influence of Rediset on moisture damage resistance 
In order to evaluate the influence of Rediset on moisture damage, the retained tensile strength after 7 days and 14 days moisture conditioning were obtained by dividing the wet tensile strength by the dry tensile strength, with the results showing in Figure 14. Due to the difficulties to achieve aggregate substrates, only modified binder with $3 \%$ dosage Rediset was selected to compare with the base bitumen. From this figure it can be seen that the retained tensile strength for all specimens experienced a declining trend after moisture conditioning. It should be noticed that the declining rates of tensile strength are different due to different aggregate-bitumen combinations. For base bitumen, specimen prepared with limestone retained $81 \%$ of its tensile strength after 14 days conditioning, which is obviously higher than the granite specimen with only $52 \%$ of its tensile strength retained. This is because the bonds formed between bitumen and the dominant calcite in limestone are very stable, even in the presence of water. In contrast, the dominant phase of albite and quartz in granite, are considered to be sensitive to moisture attack [32]. As the limestone showed good resistance to moisture damage, the addition of Rediset seems cannot influence the retained tensile strength with results being nearly the same as the specimens prepared with base bitumen. However, in terms of the granite, the Rediset significantly improved the retained tensile strength with the value increased from $52 \%$ for base bitumen to $65 \%$ for Rediset modified binder. This indicated that the anti-stripping agents in Rediset promoted the aggregate-bitumen adhesion which in turn improved the moisture susceptibility of asphalt mixtures. Based on this, it is reasonable to state that the Rediset is able to improve the moisture resistance of aggregate-bitumen combinations when moisture sensitive aggregate is used. In contrast, for aggregates with good moisture resistance, the Rediset seems have no improvement on its moisture susceptibility. 


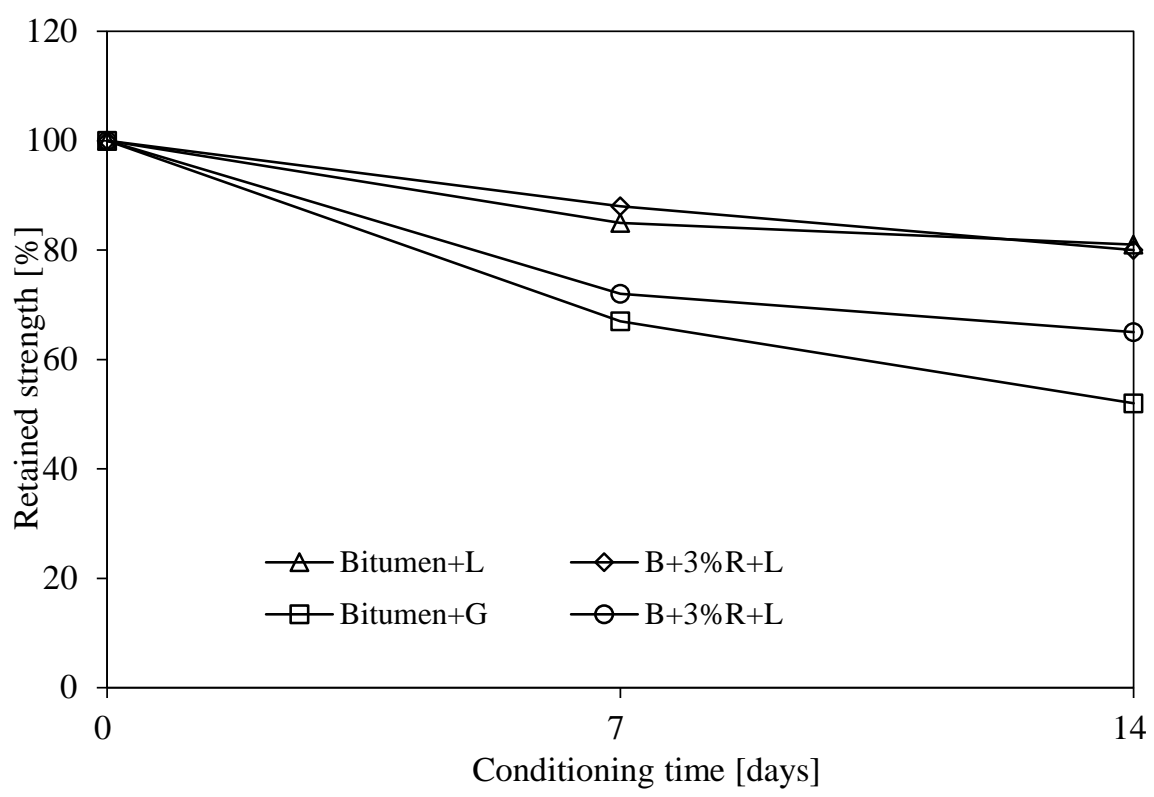

Figure 14. Retained tensile strength obtained from the PATTI test after moisture conditioning showing the effect of Rediset on different aggregate-bitumen combinations. (Note: L means limestone)

\section{Conclusions}

This paper reports findings from the effect of Rediset on the surface energy, rheological property and dynamic viscosity of bitumen as well as the aggregate-bitumen bonding strength and its resistance to moisture attack. The major findings from this study were as follows:

- Based on the DCA test, Rediset reduces the surface energy of bitumen. Under this condition, the decrease in surface energy improves the wettability of aggregate by bitumen and reduces the interfacial frictions between bitumen film and aggregate. This demonstrated that the Rediset decreases the production and compaction temperatures of asphalt mixtures.

- With the addition of Rediset, the complex modulus and phase angle has no change at high frequencies, which corresponds to low service temperatures. But at low frequencies, the complex modulus experienced an increase with the addition of 
Rediset, while the phase angle has an obvious decrease. This indicated that the Rediset improved the elastic behaviour of bitumen at high in-service temperatures which in turn improved the rutting resistance of asphalt mixture.

- All bitumen specimens in this research are Newtonian fluids at the temperature range from $100^{\circ} \mathrm{C}$ to $150^{\circ} \mathrm{C}$. Rediset reduces the viscosity of bitumen, which indicating reduced mixing and compacting temperatures of asphalt mixture.

- The PATTI test detected that the Rediset improved the bonding strength of aggregate-bitumen combinations at medium and high service temperatures which demonstrating the improvement in cracking and deformation resistance. However, the Rediset cannot influence the bonding strength at low service temperatures which means the Rediset has no contribution to the thermal cracking resistance.

- The influence of Rediset on moisture damage of aggregate-bitumen combinations was characterised by dividing the wet tensile strength by the dry tensile strength. The results show that the Rediset is able to increase the retained tensile strength which in turn improves the moisture resistance of aggregate-bitumen combinations.

- It should be mentioned that the results presented in this article are based on properties related to modified bitumen. In further steps, the asphalt mixture will be prepared and the influence of Rediset modified bitumen on related properties will be evaluated.

\section{References}

1. Zhang J, Apeagyei AK and Airey GD, et al. Influence of aggregate mineralogical composition on water resistance of aggregate-bitumen adhesion. International Journal of Adhesion and Adhesives 2015; 62: 45-54.

2. Chen ZW, Wu SP and Xiao Y, et al.. Effect of hydration and silicone resin on Basic 
Oxygen Furnace slag and its asphalt mixture. Journal of Cleaner Production 2016; 112: $392-400$.

3. Newcomb D. An introduction to warm-mix asphalt. National Asphalt Pavement Association, 2007.

4. Jamshidi A, Hamzah MO and You Z. Performance of warm mix asphalt containing Sasobit: State-of-the-art. Construction and Building Materials 2013; 38: 530-553.

5. Cui PQ, Wu SP and Xiao Y et al. Inhibiting Effect of Layered Double Hydroxides on the Emissions of Volatile Organic Compounds from Bituminous Materials. Journal of Cleaner Production 2015; 108: 987-991.

6. Pan P, Wu SP, Xiao Y and Liu G. A review on hydronic asphalt pavement for energy harvesting and snow melting. Renewable \& Sustainable Energy Reviews 2015; 48: 624 634.

7. Xiao F, Amirkhanian S N. Effects of liquid antistrip additives on rheology and moisture susceptibility of water bearing warm mixtures. Construction and Building Materials 2010; 24(9): 1649-1655.

8. D'Angelo JA, Harm EE and Bartoszek JC, et al. Warm-mix asphalt: European practice. American Trade Initiatives: 2008.

9. Mo L, Li X, Fang X, et al. Laboratory investigation of compaction characteristics and performance of warm mix asphalt containing chemical additives. Construction and Building Materials 2012; 37: 239-247.

10. Peinado D, de Vega M, Garcia-Hernando N and Marugan-Cruz C. Energy and exergy analysis in an asphalt plant's rotary dryer. Applied Thermal Engineering 2011; 31: 1039-1049 
11. Chowdhury A and Button JW. A review of warm mix asphalt. Texas Transportation Institute, the Texas A\&M University System, 2008.

12. Rubio MC, Martínez G and Baena L, et al. Warm mix asphalt: an overview. Journal of Cleaner Production 2012; 24: 76-84.

13. Gonzalez A, Cubrinovski M and Pidwerbesky B, et al. Full-Scale Experiment on Foam Bitumen Pavements in an Accelerated Testing Facility. Transportation Research Record: Journal of the Transportation Research Board 2009; (2094): 21-29.

14. Guo N, You Z and Zhao Y, et al. Laboratory performance of warm mix asphalt containing recycled asphalt mixtures. Construction and Building Materials, 2014, 64: 141-149.

15. Xiao FP, Punith VS and Amirkhanian SN. Effects of non-foaming WMA additives on asphalt binders at high performance temperatures. Fuel 2012; 94: $144-55$.

16. Kheradmand B, Muniandy R and Hua LT, et al. An overview of the emerging warm mix asphalt technology. International Journal of Pavement Engineering 2014; 15(1): 79-94

17. Zhu H, Xie ZX and Fan WZ, et al. Effects of warm mix asphalt (WMA) additives on the properties of WMA mixtures. Applied Mechanics and Materials 2013; 275: 2097-2102

18. Hailesilassie BW, Schuetz P and Jerjen I, et al. Dynamic X-ray radiography for the determination of foamed bitumen bubble area distribution. Journal of Materials Science 2015; 50(1): 79-92.

19. Patel DK, Mishra CB and Amin AA. Experimental Investigation of Warm Mix Using Rediset as additive with PMB 40 in Mix Design. International Journal of Current Engineering and Technology 2014; 4(3): 1460-1464.

20. Prowell BD, Hurley GC and Frank B. Warm-mix asphalt: Best Practices. USA: National 
Asphalt Pavement Association 2007.

21. Hamzah M, Golchin B, Jamshidi A and Chailleux E. Evaluation of Rediset for use in warm-mix asphalt: a review of the literatures. International Journal of Pavement Engineering 2015; 16: 809-831

22. Zhang JZ, Airey GD and Grenfell JRA. Experimental evaluation of cohesive and adhesive bond strength and fracture energy of bitumen-aggregate systems. Materials and Structures 2016; 49(7): 2653-2667.

23. Zhang JZ, Wu SP, Van de Ven M, et al. Dynamic viscosity analysis of base bitumen with the addition of Rediset. Advanced Materials Research 2012; 476: 1621-1625.

24. Ahmad N. Asphalt Mixture Moisture Sensitivity Evaluation using Surface Energy Parameters (PhD dissertation). University of Nottingham, 2011

25. Bhasin A. Development of methods to quantify bitumen-aggregate adhesion and loss of adhesion due to water (PhD dissertation). Texas A\&M University, College Station, Texas, USA 2006.

26. Liu $\mathrm{G}, \mathrm{Wu} \mathrm{S}$ and Van de Ven $\mathrm{M}$, et al. Influence of sodium and organo-montmorillonites on the properties of bitumen. Applied Clay Science 2010; 49(1): $69-73$.

27. Santagata FA, Cardone F, Canestrari F and Bahia HU. Modified PATTI test for the characterization of adhesion and cohesion properties of asphalt binders. International Conference on Maintenance and Rehabilitation of Pavements and Technological Control, Sixth Proceedings, Turin, 2009.

28. Arega Z. and Bhasin A. Interim report: Binder rheology and performance in warm mix asphalt. FHWA/TX-12/0-6591-2. USA: Center for Transportation Research 2012, The University of Texas at Austin. 
29. Capitao SD, Picado-Santos LG, and Martinho F. Pavement engineering materials: Review on the use of warmmix asphalt. Construction and Building Materials 2012; 36: 1016-1024.

30. Naskar M, Reddy KS and Chaki T K, et al. Effect of ageing on different modified bituminous binders: comparison between RTFOT and radiation ageing. Materials and Structures 2013; 46(7): 1227-1241.

31. Chen JS, Huang CC and Chu P Y, et al. Engineering characterization of recycled asphalt concrete and aged bitumen mixed recycling agent. Journal of Materials Science 2007; 42(23): 9867-9876.

32. Apeagyei AK, Grenfell $\mathrm{J}$ and Airey GD. Moisture-induced strength degradation of aggregate-asphalt mastic bonds. Road Materials and Pavement Design 2014; 15(1): 239-262. 